\title{
PREVALENCE OF INTESTINAL PARASITES AND ITS IMPACT ON NUTRITIONAL STATUS AMONG PRESCHOOL CHILDREN LIVING IN DAMANHUR CITY, EL-BEHERA GOVERNORATE, EGYPT
} By

ADHAM MOHAMMAD HEGAZY ${ }^{1}$, NEVEEN TAWAKOL YOUNIS ${ }^{1}$, HEBA ABDELKADER AMINOU ${ }^{2}$ AND AYMAN MOHAMED BADR ${ }^{3}$

Departments of Pediatric ${ }^{1}$, and Parasitology ${ }^{2}$, Faculty of Medicine, Ain Shams University, Cairo 11566, and Ministry of Health and Population ${ }^{3}$, Cairo, Egypt

\begin{abstract}
This cross sectional study was done in Damanhur City, the Capital of El-Behera Governorate to detect the prevalence of intestinal parasitic infection among preschool aged children and to find out its effect on their nutritional status. Five-hundreds children aged between 2-6 years were enrolled; a detailed questionnaire, complete clinical and anthropometric assessment as well as complete stool analysis and blood picture were done. The study revealed that $51.8 \%$ preschool children were infected; Cysts of Entamoeba histolytica and Giardia lamblia were found in $16.8 \%$, and $14.8 \%$ respectively. In $1.8 \%$ of cases, both cysts were found together. Ova of Ascaris lumbricoides, Enterobius vermicularis, Ancylostoma duodenale and Hymenolepis nana were detected in $14 \%, 3.4 \%, 5 \%$ \& $0.2 \%$ of cases, respectively. In $0.4 \%$ of cases, ova of $A$. lumbricoides and E. vermicularis were found together. Mixed infections were found in $3.6 \%$ of children. Significantly lower weight for age z-score (WAZ) and weight for height z-score (WHZ) were found among infested children compared to non-infested ones $(\mathrm{P}<0.05)$. Moreover, stunting was found in $44.1 \%$, underweight in $39.1 \%$ and wasting in $11.5 \%$ of infested children. Prevalence of anemia among all studied population was $39 \%$; $48.6 \%$ in infested group compared to $28.8 \%$ in non-infested children ( $\mathrm{x}=20, \mathrm{P}<0.001)$. Improper hand washing, and playing in the street bare footed, together with playing with animals and family history of parasitic infestation were considered the independent predictors of parasitic infestation by using binary logistic regression.
\end{abstract}

Key words: Egypt, Preschool-children, Intestinal Parasites, Nutrition, anthropometric measurements

\section{Introduction}

Although all infectious agents in humans are parasites, by convention, parasitic diseases are defined as those caused by protozoa or helminthes (Chacon-Cruz and Mitchell, 2007). Intestinal parasitic infection is a serious public health problem world-0wide particularly in developing countries (Quihui et al, 2006). It is a well-known fact that parasitic infections are more common in pediatric age group as children are more vulnerable population. The consequences of these parasitic infections result in mal-nutrition, anemia, cognitive impairment and increased susceptibility to other infections (Östan et al, 2007). Various risk factors are responsible for this prevalent disease, which include low socioeconomic status, poor hygienic conditions, impure drinking water, low literacy rate of parents, large size of the family and poor health status of the child (Okyay et al, 2004).

In Egypt, $56.0 \%$ and $47.0 \%$ of children suffered from intestinal parasites and anemia, respectively (UNICEF, 2000). There has been an increased awareness of the public health importance of parasitic infections, but much of the interest was focused on chemotherapy as a means of control while the study of social, cultural and economic factors underlying infection risk has been relatively neglected (Boatin et al, 2012).

This study aimed to investigate the prevalence of intestinal parasitic infection among preschool-aged children living in Damanhur City, El-Behera Governorate and to assess its impact on nutritional status of those children.

Subjects, Materials and Methods 
This cross sectional study was conducted on 500 preschool children (2-6 years) living in different areas in Damanhur City. They were taken randomly after excluding the following criteria: Children with systemic diseases that could affect nutritional status, Children with history of blood transfusion or hereditary blood disease, and Children took anthelminthic drugs during the last 6 months.

A detailed questionnaire was filled up considering the different variables, with estimation of social status (Park and Park, 1979). They were subjected to complete clinical examination with special emphasis on anthropometric measurements; weight, height, skull circumference, left mid arm circumference and body mass index (BMI), and calculation of Z-scores (WHO, 2006) growth charts. Laboratory investigations included complete blood count (CBC) by Sysmex XT-1800i (Sysmex, Kobe, Japan), stool analysis macroscopically for pin-worms, cestod-segments, blood, mucus and consistency and microscopically by direct wet mount method (Cheesbrough, 2004) after staining with haematoxylin an eosin as well as Lugol iodine solutions. For the detection of Cryptosporidium oocysts, smears from fecal samples were prepared on glass slides using sterile swabs, dried and stained by modified Ziehl-Nielsen (acid-fast) method (Garcia et al, 1983). Stool analysis by KatoKatz method (Katz et al., 1972) was done whenever indicated.

Statistical analysis: Standard computer program SPSS for Windows, release 13.0 (SPSS Inc, USA) was used for data entry and analysis. Quantitative variables are presented as mean \pm standard deviation (SD) while qualitative variables as number and percentage. Comparison of different variables in various groups was done using student $\mathrm{t}$ and Mann Whitney tests for normal and nonparametric variables respectively. Chi-square test was used to compare frequency of qualitative variables among different groups. Binary logistic regression analysis was used to find out the significant independent predictors of special dependent variable by using backward likelihood ratio technique. For all tests a probability (p) less than 0.05 was considered significant (Miller, 1992).

\section{Results}

The results are shown in tables $(1,2,3,4,5,6 \& 7)$.

Table 1: Demographic data of children

\begin{tabular}{|l|l|l|l|l|}
\hline Variables & $\begin{array}{l}\text { Non infected children } \\
(\mathrm{n}=241)\end{array}$ & $\begin{array}{l}\text { Infected children } \\
(\mathrm{n}=259)\end{array}$ & $\mathrm{X}^{2}$ & $\mathrm{P}$ \\
\hline Age (months) & $50.9 \pm 9.5$ & $49.3 \pm 8$ & 1 & $>0.05$ NS \\
\hline Male & $120(49.8 \%)$ & $135(52.1 \%)$ & 0.9 & $>0.05 \mathrm{NS}$ \\
Female & $121(50.2 \%)$ & $124(47.9 \%)$ & & $<0.001 \mathrm{HS}$ \\
\hline Social class & $37(15.4 \%)$ & $119(45.9 \%)$ & 66 & \\
Low & $35(39.4 \%)$ & $92(35.5 \%)$ & & \\
Middle & $109(45.2 \%)$ & $48(18.5 \%)$ & & $<0.001 \mathrm{HS}$ \\
High & $50(20.7 \%)$ & $142(54.8 \%)$ & 61 & $<0.001 \mathrm{HS}$ \\
\hline Past history of parasitosis & $230(89.1 \%)$ & 31 & \\
\hline Family history of parasitosis & $166(68.9 \%)$ & & & \\
\hline
\end{tabular}

Table 2: Recovered parasites from the preschool aged children in Damanhur City

\begin{tabular}{|l|c|} 
Parasites detected & Infected children \\
\hline Entamoeba histolytica & $16.8 \%$, \\
\hline Ascaris lamblia & $14.8 \%$ \\
\hline Enterobius vermicoides & $14 \%$, \\
\hline Ancylostoma duodenale & $3.4 \%$ \\
Hymenolepis nana & $5 \%$ \\
\hline
\end{tabular}


Table 3: Comparison between children with and without parasitic infection regarding hygienic habits

\begin{tabular}{|l|c|c|c|c|}
\hline Variables & Non infected & Infected children & $\mathrm{X}^{2}$ & $\mathrm{P}$ \\
\hline Hand washing before meals & $196(81.3 \%)$ & $102(39.4 \%)$ & 91 & $<0.001 \mathrm{HS}$ \\
\hline Hand washing after defecation & $184(76.3 \%)$ & $97(37.5 \%)$ & 76 & $<0.001 \mathrm{HS}$ \\
\hline Swimming in canals & $15(6.2 \%)$ & $79(30.5 \%)$ & 48 & $<0.001 \mathrm{HS}$ \\
Trimming of finger nails & $152(63.1 \%)$ & $106(40.6 \%)$ & 24 & $<0.001 \mathrm{HS}$ \\
\hline Play in street bare footed & $123(51 \%)$ & $236(91.1 \%)$ & 99 & $<0.001 \mathrm{HS}$ \\
Play with animals & $26(10.8 \%)$ & $115(44.4 \%)$ & 69 & $<0.001 \mathrm{HS}$ \\
\hline Proper washing of veg. \&fruits & $227(94.2 \%)$ & $232(89.6 \%)$ & 3.5 & $<0.05 \mathrm{~S}$ \\
\hline Proper cooking of meat and fish & $241(100 \%)$ & $258(99.6 \%)$ & 0.9 & $>0.05 \mathrm{NS}$ \\
\hline
\end{tabular}

Table 4: Comparison between cases with and without parasitic infection regarding clinical manifestations

\begin{tabular}{|l|c|c|c|c|}
\hline Variables & Non infected & Infected children & $\mathrm{X}^{2}$ & \multicolumn{2}{|c|}{$\mathrm{P}$} \\
\hline Abdominal Colic & $64(26.7 \%)$ & $195(75.6 \%)$ & 119 & $<0.001 \mathrm{HS}$ \\
\hline Constipation & $7(2.9 \%)$ & $72(27.8 \%)$ & 58 & $<0.001 \mathrm{HS}$ \\
\hline Diarrhea & $7(2.9 \%)$ & $45(17.4 \%)$ & 28 & $<0.001 \mathrm{HS}$ \\
\hline Vomiting & $3(1.2 \%)$ & $15(5.8 \%)$ & 7.5 & $<0.05 \mathrm{~S}$ \\
\hline Urinary incontinence & $105(43.6 \%)$ & $141(54.4 \%)$ & 5 & $<0.05 \mathrm{~S}$ \\
\hline Passage of worm segment & $1(0.4 \%)$ & $49(18.9 \%)$ & 47 & $<0.001 \mathrm{HS}$ \\
\hline Fatigue & $44(18.6 \%)$ & $92(35.5 \%)$ & 17.6 & $<0.001 \mathrm{HS}$ \\
\hline Lack of concentration & $50(21.1 \%)$ & $110(42.5 \%)$ & 25 & $<0.001 \mathrm{HS}$ \\
\hline Palpitation & $7(2.9 \%)$ & $29(11.2 \%)$ & 13 & $<0.001 \mathrm{HS}$ \\
\hline Peri anal itching & $2(0.8 \%)$ & $84(32.4 \%)$ & 87 & $<0.001 \mathrm{HS}$ \\
\hline Increase appetite & $109(45.2 \%)$ & $64(24.7 \%)$ & 23 & $<0.001 \mathrm{HS}$ \\
\hline Decrease appetite & $129(53.8 \%)$ & $192(74.1 \%)$ & 22.4 & $<0.001 \mathrm{HS}$ \\
\hline Weight loss & $51(21.2 \%)$ & $128(49.6 \%)$ & 43 & $<0.001 \mathrm{HS}$ \\
\hline Tenismus & $4(1.7 \%)$ & $70(27 \%)$ & 63 & $<0.001 \mathrm{HS}$ \\
\hline Bloody stool & $1(0.4 \%)$ & $34(13.1 \%)$ & 30 & $<0.001 \mathrm{HS}$ \\
\hline Fever & $6(2.5 \%)$ & $16(6.2 \%)$ & 4 & $<0.05 \mathrm{~S}$ \\
\hline Pallor & $177(75 \%)$ & $228(89.4 \%)$ & 18 & $<0.001 \mathrm{HS}$ \\
\hline Abdominal distention & $7(2.9 \%)$ & $126(48.8 \%)$ & 134 & $<0.001 \mathrm{HS}$ \\
\hline Lymphadenopathy & 0 & $2(0.8 \%)$ & 0.2 & $>0.05 \mathrm{NS}$ \\
\hline pityriaisis alba & $164(68 \%)$ & $219(84.6 \%)$ & 19 & $<0.001 \mathrm{HS}$ \\
\hline
\end{tabular}

Table 5: Comparison between children with and without parasitosis regarding anthropometric measurements

\begin{tabular}{|c|c|c|c|c|}
\hline $\begin{array}{l}\text { Variables } \\
\text { WAZ } \\
\text { At risk }(-1>\text { SD }>-2) \\
\text { Under weight }(<-2 \text { SD })\end{array}$ & $\begin{array}{l}\text { Non infected } \\
37(74 \%) \\
13(26 \%)\end{array}$ & $\begin{array}{l}\text { Infected children } \\
56(60.9 \%) \\
36(39.1 \%)\end{array}$ & $\begin{array}{l}X^{2} \\
3\end{array}$ & $\begin{array}{l}\mathrm{P} \\
<0.05 \mathrm{~S}\end{array}$ \\
\hline $\begin{array}{l}\text { HAZ } \\
\text { At risk }(-1>\text { SD }>-2) \\
\text { Stunted }(<-2 \text { SD) } \\
\text { HCZ } \\
\text { At risk }(-1>\text { SD }>-2) \\
\text { Below average }(<-2 \text { SD) }\end{array}$ & $\begin{array}{l}65(59.1 \%) \\
45(40.9 \%) \\
20(87 \%) \\
3(13 \%) \\
\end{array}$ & $\begin{array}{l}76(55.9 \%) \\
60(44.1 \%) \\
35(79.5 \%) \\
9(20.5 \%) \\
\end{array}$ & $\begin{array}{l}0.2 \\
0.6\end{array}$ & $\begin{array}{l}>0.05 \mathrm{NS} \\
>0.05 \mathrm{NS}\end{array}$ \\
\hline $\begin{array}{l}\text { WHZ } \\
\text { At risk of wasting }(-1>\mathrm{SD}>-2) \\
\text { Wasting }(<-2 \mathrm{SD}) \\
\text { Over weight }(1<\mathrm{SD}<2) \\
\text { Obese }(>2 \mathrm{SD})\end{array}$ & $\begin{array}{l}19(9.6 \%) \\
15(5.5 \%) \\
46(47.4 \%) \\
17(7.5 \%)\end{array}$ & $\begin{array}{l}35(36.5 \%) \\
11(11.5 \%) \\
36(37.5 \%) \\
14(14.6 \%)\end{array}$ & 6.8 & $<0.05 \mathrm{~S}$ \\
\hline $\begin{array}{l}\text { Left mid arm circumference } \mathrm{Z} \\
\text { BMI Z }\end{array}$ & $\begin{array}{l}-0.68+55 \\
-1.10 \pm 0.50\end{array}$ & $\begin{array}{l}-0.67 \pm 0.45 \\
-0.97 \pm 0.45\end{array}$ & $\begin{array}{l}1.7 \# \\
1.4 \#\end{array}$ & $\begin{array}{l}>0.05 \mathrm{NS} \\
>0.05 \mathrm{NS}\end{array}$ \\
\hline
\end{tabular}

Regarding CBC picture, significantly lower values of hemoglobin $(\mathrm{Hb})$ and mean corpuscular volume (MCV) were found among infested children (table 5). Prevalence of anemia among all studied population was $39 \%$ (48.6\% of infested children compared to $28.8 \%$ in non-infected group $(\mathrm{x}=20, \mathrm{P}<0.001)$ 
Table 6: Comparison between children with and without parasitic infestation regarding CBC picture

\begin{tabular}{|c|c|c|c|c|}
\hline Variables & Non infested & Infested children & t-test & P \\
\hline HB & $11.1 \pm 4$ & $10.8+2.5$ & 4 & $<0.001 \mathrm{HS}$ \\
\hline RBCs & $4.4 \pm 1.2$ & $4.3 \pm 1.5$ & 1.9 & $>0.05 \mathrm{NS}$ \\
\hline Hematocrit value & $34.6+3$ & $33.8+2.6$ & 1.7 & $>0.05 \mathrm{NS}$ \\
MCV & $78.6 \pm 7.6$ & $76 \pm 6$ & 3 & $<0.001 \mathrm{HS}$ \\
\hline MCH & $25.4+3$ & $25.4+6$ & 0.8 & $>0.05 \mathrm{NS}$ \\
MCHC & $40 \pm 15.7$ & $31.6 \pm 13$ & 1.6 & $>0.05 \mathrm{NS}$ \\
\hline RDW & $13.3 \pm 3$ & $13 \pm 2.6$ & 1.1 & $>0.05 \mathrm{NS}$ \\
\hline Platelets & $390 \pm 146$ & $319 \pm 80$ & 0.6 & $>0.05 \mathrm{NS}$ \\
\hline TLC & $7.2+3$ & $8.2+1.7$ & 1.2 & $>0.05 \mathrm{NS}$ \\
\hline
\end{tabular}

$\mathrm{HB}=$ hemoglobin, $\mathrm{RBCs}=$ red blood cells, $\mathrm{MCV}=$ corpuscular volume, $\mathrm{MCH}=$ corpuscular hemoglobin, $\mathrm{MCHC}=$ corpuscular hemoglobin concentration, $\mathrm{RDW}=$ red cell distribution width, TLC- total leucocytic count.

Table 7: Relation between different risk factors versus parasitic infestation by logistic regression

\begin{tabular}{|l|c|c|c|}
\hline Independent predictors & Beta-coefficient & $\mathrm{P}$ & Odd's (95\%CI) \\
Hand washing before & -1.3 & $<0.001 \mathrm{HS}$ & $5(1.2-17.8)$ \\
\hline Playing bare footed & 1.1 & $<0.001 \mathrm{HS}$ & $2.5(1-11.4)$ \\
\hline Playing with animals & 1.1 & $<0.001 \mathrm{HS}$ & $2.3(1.1-16)$ \\
\hline Family history of parasitosis & 0.83 & $<0.05 \mathrm{~S}$ & $2.2(1-15.7)$ \\
\hline
\end{tabular}

\section{Discussion}

In the present study, parasitic infection was found in 259 children (51.8\%). Entamoeba histolytica and Giardia lamblia cysts were found in $16.8 \%$, \& $14.8 \%$ respectively, and double infection with both was in $1.8 \%$. Ova of Ascaris lumbricoides, Enterobius vermicularis, Ancylostoma duodenale and Hymenolepis nana were detected in $14 \%$, $3.4 \%, 5 \% \& 0.2 \%$ of cases respectively. Double infection with both was found in $0.4 \%$. Mixed infections were found in $3.6 \%$ of children. Demographic data revealed that low social class and positive family and past history of parasitic infestation were significantly higher among infested group (Tab.1). El-Gammal et al. (1995) in Egypt reported that the prevalence of parasitic infection among school children in Malames village in Lower Egypt was $31.9 \%$ and $88.5 \%$ in Tamouh and Demo villages in Upper Egypt. El-Masry et al. (2007) in Sohag Governorate (Upper Egypt) found that $38.5 \%$ of school students in a village in Tahta District had parasitic infection. Among Egyptian youth and adults, Bakr et al. (2009) in village, Menoufia Governorate reported 47.8\% with at least a single parasite and Mousa et al. (2010) in Cairo found an overall parasitic infection of $60.9 \%$ among patients suffering from diarrhea. Abroad, Rim et al. (2003) in
Laos found that $61.9 \%$ of primary school children had intestinal helminthes. These differences of prevalence may be attributed to difference in sites, human habitats, ages, sanitation levels, water supply, hygienic measures and food behaviors.

In the present study, the preschool aged children showed an overall infection rate of $51.8 \%$. Abroad, Mumtaz et al. (2009) in Karachi found parasitic infection in $68.8 \%$ of children less than 5 years old. Niyizurugero et al. (2013) in Rwanda found parasitic infection in $50.5 \%$ of preschool aged children. Suchdev et al. (2014) in Kenya reported parasitic infection in $40 \%$ of preschool aged children.

The present study showed that protozoa were detected in $33.4 \%$ of children; $16.8 \%$ E. histolytica, $14.8 \%$ G. lamblia and $1.8 \%$ as double infection. Chacon-Cruz and Mitchell (2007) mentioned an overall world estimation $10 \%$ to be infected with E. histolytica; the highest was in developing countries with the lowest levels of sanitation, and that $G$. lamblia jumped to $20-40 \%$ in developing countries, especially among children.

El Masry et al. (2007) among school aged children reported G. lamblia in $15.2 \%$ and $E$. histolytica in 20.4\%. Bakr et al. (2009) detected E. histolytica in $20 \%$ of cases, E. coli in $10 \%$ and G. lamblia in $10 \%$. 
Handousa et al. (2007) in Dakahlia Governorate reported insignificant difference between symptomatic and asymptomatic groups regarding the prevalence of different Giardia genotypes and the prevalence of CD4 and CD8 lymphocyte infiltration grading in different Giardia genotypes. AbouShady et al. (2011) in Egypt found that most giardiasis-infected children were between 1 and 5 years, with significant affection of weight, abdominal pain, and/or intermittent diarrhea. Serum zinc and iron levels were significantly decreased in the infected group compared to control $(\mathrm{P}<0.001)$. El-Gebaly et al. (2012) in Cairo evaluated detection of giardiasis in preschool-children. They concluded that the advantage of salivary assays over serum immunoglobulin assay was being easy and non-invasive in sampling technique especially for young children. Eldash et al. (2013) in Saudi Arabia found giardiasis in $47(52.2 \%)$ patients and $30(33.3 \%)$ controls with a statistically significant difference $p=0.02$, and that the incidence among cases was higher among age group above 5 years $(\mathrm{p}=0.001)$, as a significant predictor for RAP. They concluded that association of $H$. pylori and $G$. intestinalis was among $36(40.0 \%)$ patients and $11(12.2 \%)$ controls with a significant difference.

In the present study, the children were Cryptosporidium parvum free. In Egypt, Cryptosporidiosis was reported as zoonosis (Youssef et al, 2008) and nosocomial in a pediatric hospital (El-Sibaei et al, 2003).

In this study, helminthes were detected in $22.8 \%$ of preschool aged children; $14 \% \mathrm{~A}$. lumbricoides, $3.4 \%$ E. vermicularis and $0.4 \%$ with double infection, $5 \% \mathrm{~A}$. duodenale and $0.2 \% H$. nana. In addition, mixed infections (protozoa and helminthes) were found in $3.6 \%$ of children. El-Masry et al. (2007) found $E$. vermicularis in $16.6 \%, H$. nana in $14.9 \%$ and $A$. lumbricoides in $6.5 \%$. Rim et al. (2003) abroad detected higher prevalence of $A$. lumbricoides (34.9\%), hook worm (19.1\%) and T. trichiura (25.8\%).

In the present study, none was infected with Fasciola spp. Rashed et al. (2010) in Egypt stated that nearly 24 million Egyptians at risk and about 800,000 were infected. On the global scale, about 180 million are at risk of infection. They added that all ages and both sexes were susceptible to fascioliasis infection and that watercress topped the list of the Egyptian plants born encysted metacercariae followed by lettuce, mint, and alfalfa. No doubt, the establishment of rapid and dependable sero-diagnosis (Rabee et al, 2013), the control measures of snails intermediate hosts (Dar et al, 2014) and availability of treatment explained the absence of fascioliasis in the group.

In the present study, the social status of infected children was significantly lower than in non-infected ones. Also, logistic regression showed that improper hand washing and playing in the street bare footed, together with playing with animals and family history of parasitic infection were considered the independent predictors of parasitosis.

El Masry et al. (2007) found that poor personal hygiene, low socioeconomic level, $\geq 3$ infected siblings, previous parasitic infections and no early consultation for therapy were important risk factors. Bakr et al. (2009) found on multiple logistic regression analysis; the risk factor most strongly associated with infection was the presence of another infected family member. Mousa et al. (2010) reported that the risk factors rural areas, education level, contact with farm animals and/ or pet animals. El-Sherbini and Abosdera (2013) in Giza stated that poverty, illiteracy, poor hygiene, lack of access to clean water and tropical climate were the factors associated with intestinal parasitic infections all correlated positively with increased rates of infection among school children.

In the present study, clinical characteristics of infected children showed that abdominal colic and anorexia were the commonest symptoms, while pallor and pityriaisis alba were the commonest signs. El Masry et al. 
(2007) reported $60.3 \%, 52.4 \%, 51.9 \%$, $45.4 \%, 34.3 \%$ of students with positive parasitic infections suffered from headache, fatigue, pallor, loss of appetite, abdominal colic respectively. Also, Al-Haddad and Baswaid (2010) in Yemen found similar presentations among the studied cohort. Elwakil and Talaat (2009) reported that the frequency of intestinal symptoms was $64 \%$ in protozoan cases. Abdominal pain was the most frequent symptom 78\% (7/9), but without definite correlation between RFLPbanding pattern or genetically distinct genotypes and pathogenecity. Moreover, pallor was the commonest sign of anemia as a public health problem among parasitic infection children overwhelms (El Masry et al, 2007; Mumtaz et al, 2009; Suchdev et al, 2014).

Generally speaking, Curtale et al. (2003) in El-Berea stated that school health programs offer the opportunity to deliver public health interventions to a great number of beneficiaries at a relatively low cost and are seen with growing interest by policy makers in developing countries and the donors' communities. A pilot school health program was implemented for the past 6 years in ElBehera, the largest and most populous Governorate of the Nile Delta. Program integrated additional activities for control of soiltransmitted helminthiasis, human fascioliasis and anemia in the National Schistosomiasis Control Program (NSCP), implemented in Egypt since 1988 by the Ministry of Health and Population (MoHP). To facilitate planning and direct actions, a strong monitoring system was also developed, that generated useful information for the schistosomiasis control program. The practical steps adopted to develop the program were presented and discussed. They concluded that three rounds of monitoring (2000, 2001\& 2002) were analyzed and compared with baseline data conducted in 1996, together with each activity cost. On the basis of the experience gained by El-Behera school health program a number of operational recommendations were formulated.
The present study showed significantly lower Z-score values of WAZ and WHZ among children with parasitic infestation compared to those without infestation. Although height for age z-score (HAZ) values were lower in infested children yet did not reach a statistical significant difference from non-infested group. Further, stunting was found in $44.1 \%$ of infested children, underweight in $39.1 \%$, wasting in $11.5 \%$. Actually, malnutrition and parasitic infestation are commonly associated. ElMasry et al. (2007) found height for age less than 5th percentile in $31.6 \%$ and weight for age less than 5 th percentile in $29.2 \%$ among Students with positive parasitic infection that was significantly higher than in negative cases. Also, Jiménez Gutiérrez et al. (2014) showed that children with parasitic infections had lower HAZ scores (mean of -1.449) than the reference population. Belizario et al. (2011) found overall prevalence of school children with below normal weight for age was $29.9 \%$, while prevalence of those with below normal height for age and BMI for age was $42.8 \%$ and $14.9 \%$, respectively. In Mumtaz et al. (2009) study, 29.4\% of the children less than 5 years were mildly malnourished while $20.4 \%$ showed moderate malnutrition. Suchdev et al. (2014) found stunting in preschool and school children with parasitic infestation $(29.7 \%$ and $16.9 \%$, respectively).

Parasitic infections are thought to contribute to child malnutrition, micronutrient deficiency and protein loss through subtle reduction in digestion and absorption, chronic inflammation and loss of nutrients. Childhood is the time of intense growth; it is the period in which the velocity of individual's growth had a rapid increase (Rees et al, 1999).

Regarding CBC picture, the prevalence of anemia among our studied population was $39 \%$ with significantly higher proportions among infested children $(48.6 \%$ versus 28.8\%). The Egyptian studies showed anemia was in $52.4 \%$ of infected children and in $32.7 \%$ of non-infected students (El Masry et 
$a l, 2007$ ), and WHO/WEE (2006) reported that parasitic infections were usually associated with different types of anemia.

Studies in other countries also showed an association between parasitic infection and anemia; Mumtaz et al. (2009) reported that $44.6 \%$ of infected children less than 5 years were found to have mild anemia. Also, Suchdev et al. (2014) revealed anemia in $38.3 \%$ and $14.0 \%$ of preschool and school aged children respectively.

\section{Conclusion}

The outcome results showed that $51.8 \%$ of preschool aged children had parasitic infections in Damanhur City that affected their growth and nutritional status.

This highlights the magnitude of the problem of parasitic infection in this young age group. So, improving personal and environmental hygienic measures, regular screening and treatment for parasitic infections among children in rural and urban areas of Egypt are warrant.

\section{References}

Abou-Shady, O, El Raziky, MS, Zaki, MM, Mohamed, RK, 2011: Impact of Giardia lamblia on growth, serum levels of zinc, copper, and iron in Egyptian children. Biol. Trace Elem. Res. 140, 1:1-6.

Al-Haddad, AM, Baswaid, SH, 2010: Frequency of intestinal parasitic infection among children in Hadhramout governorate (Yemen). J. Egypt. Soc. Parasitol. 40, 2:479-88.

Bakr, IM, Arafa, NA, Ahmed, MA, Mostafa, MH, Mohamed, MK, 2009: Prevalence of intestinal parasitosis in a rural population in Egypt, and its relation to socio-demographic characteristics. J. Egypt. Soc. Parasitol. 39, 1:S371-81.

Belizario, VY, Totañes, FI, de Leon, WU, Lumampao, YF, Ciro, RN, 2011: Soil-transmitted helminth and other intestinal parasitic infections among school children in indigenous people communities in Davao del Norte, Philippines. Acta Trop.120, 1:S12-8.

Boatin, BA, Basanez, MG, Prichard, RK, Awadzi, K, Barakat, RM, 2012: A research agenda for helminth diseases of humans: Towards control and elimination. PLoS. Negl. Trop. Dis. 6, 4:e1547.

Chacon-Cruz, E, Mitchell, DK, 2007: Intestin- al protozoal diseases. http://www. emedicine. com/ped/TOPIC1914.HTM

Cheesbrough, M, 2004: Parasitological tests. In: District laboratory diagnosis in tropical countries, Part $1,1^{\text {st }}$ edition. Cheesbrough, M. (ed.): Cambridge University Press, Cambridge CB2 2RU, United Kingdom.

Curtale, F, Abdel Wahab, Hassanein, Y, El Wakeel, A, Barduagni, P, Savioli, L, 2003: The school health programme in behera: an integrated helminth control programme at governorate level in Egypt. Acta Trop. 86, 2/3:295307.

Dar, Y, Vignoles, P, Rondelaud, D, Dreyfuss, G, 2014: Role of the lymnaeid snail Pseudosuccinea columella in the transmission of the liver fluke Fasciola hepatica in Egypt. J. Helminthol. 27:1-8.

Eldash, HH, Bekhit, OE, Algameel, AA, 2013: Impact of Helicobacter pylori-giardiasis coinfection on children with recurrent abdominal pain. J. Egypt. Soc. Parasitol. 43, 2:509-16.

El-Gammal, N, Sayed El-Ahl, S, Osman, FH, Salem, HS, 1995: Comparative study of parasitic infections among school children in two rural areas in upper Egypt (Demo village) and lower Egypt (Malames village). Egypt. J. Comm. Med. 3, 1:25-30.

El-Gebaly, NS, Halawa, EF, Moussa, HM, Rabia, I, Abu-Zekry, M. 2012: Saliva and sera IgA and IgG in Egyptian Giardia-infected children. Parasitol. Res. 111, 2:571-5.

El-Masry, HM, Ahmed, YA, Hassan, AA, Zaky, S, Abd-Allah, ES, et al, 2007: Prevalence, risk factors and impacts of schistosomal and intestinal parasitic infections among rural school children in Sohag Governorate. Egypt. J. Hosp. Med. 29: 616-30

El-Sherbini, GT, Abosdera, MM, 2013: Risk factors associated with intestinal parasitic infections among children. J. Egypt. Soc. Parasitol. 43, 1:287-94.

El-Sibaei, MM, Rifaat, MA, Hame- ed, D, ElDin, H, 2003: Nosocomial sources of cryptosporidial infection in newly admitted patients in Ain Shams University Pediatric Hospital. J. Egypt. Soc. Parasitol. 33, 1:177-88.

Elwakil, HS, Talaat, RM, 2009: Genetic analysis of Blastocystis hominis isolated from symptomatic and asymptomatic human hosts in Egypt. J. Egypt. Soc. Parasitol. 39, 1:99-109

Garcia, LS, Bruckner, DA, Brewer, TC, Shimizu, RY, 1983: Techniques for the recovery and 
identification of Cryptosopridium oocysts from stool specimens. J. Clin. Microbiol. 18: 185-90.

Jiménez Gutiérrez, E, Pineda, V, Calzada, JE, Guerrant, RL, Lima Neto, JB, et al, 2014: Enteric parasites and enteroaggregative Escherichia coli in children from Cañazas County, Veraguas Province, Panama. Am. J. Trop. Med. Hyg. 2014 Jun 30. pii: 13-0438. [Epub ahead of print]

Handousa, AE, Azab, MS, El-Beshbishi, SN, El-Nahas, HA, Abd El-Hamid, MA, 2007: Comparative study between immunohistochemical grading and giardia genotyping among symptomatic and asymptomatic humans. Egypt J. Immunol. 14, 2:63-72.

Katz, N, Chaves, A, Pellegrino, J, 1972: A simple device for quantitative stool thick-smear technique in schistosomiasis mansoni. Rev. Inst. Med. Trop. de São Paulo, 14:397-400.

Miller, MC, Knapp, RG, 1992: Clinical Epidemiology and Biostatistics. Williams \& Wilkins, Maryland: $3^{\text {rd }}$ edition, USA.

Mousa, KM, Abdel-Tawab, AH, Khalil, HH, El-Hussieny, NA, 2010: Diarrhea due to parasites particularly Cryptosporidium parvum in Great Cairo, Egypt. J. Egypt. Soc. Parasitol. 40, 2:439-50.

Mumtaz, S, Siddiqui, H, Ashfaq, T, 2009: Frequency and risk factors for intestinal parasitic infection in children under five years age at a tertiary care hospital in Karachi. J. Pak. Med. Assoc. 59, 4:216-9.

Niyizurugero, E, Ndayanze, JB, Bernard, K, 2013: Prevalence of intestinal parasitic infections and associated risk factors among Kigali Institute of Education students in Kigali, Rwanda. Trop. Biomed. 30, 4:718-26.

Okyay, P, Ertug, S, Gultekin, B, Onen, O, Beser, E, 2004: Intestinal parasites prevalence and related factors in school children, a western city sample-Turkey. BMC Pub. Health. 4:64-9.

Östan, I, Kilimciolu, AA, Girginkardeler, N, Özyurt, CB, Limoncu, ME, et al, 2007: Health inequities: lower socio-economic conditions and higher incidences of intestinal parasites. BMC Pub. Hlth. 7:342-50.

Park, JE, Park, K, 1979: Textbook of preventive social medicine, $7^{\text {th }}$ edition, Messers Banarsidas, Bhanot Publisher, 1268, Napier Town.
Quihui, L, Valencia, ME, Crompton, DWT, Phillips, S, Hagan, P, Morales, G, 2006: Role of the employment status and education of mothers in the prevalence of intestinal parasitic infections in Mexican rural school children. BMC Pub. Hlth. 6:225-32.

Rabee, I, Mahana, NA, Badr, AM, 2013: Immunodiagnosis of Egyptian human fasciolosis gigantica using Fas1 and Fas2 cysteine proteinase antigens. J. Egypt. Soc. Parasitol. 43, 3:78796

Rashed, AA, Khalil, HH, Morsy, ATA, 2010: Zoonotic ectopic fascioliasis: Review and discussion. J. Egypt. Soc. Parasitol. 40, 3:591-608.

Rees, JM, Neumark-Sztainer, D, Kohn, M, Jacobson, M, 1999: Improving the nutritional health of adolescents- Position statement- Society for adolescent medicine. J. Adolescent. Hlth. 24: 461-2.

Rim, HJ, Chai, JY, Min, DY, Cho, SY, Eom, KS, et al, 2003: Prevalence of intestinal parasite infections on a national scale among primary schoolchildren in Laos. Parasitol. Res. 91, 4: 267-72.

Suchdev, PS, Davis, SM, Bartoces, M, Ruth, LJ, Worrell, CM, Kanyi, H, Odero, K, Wiegand, RE, Njenga, SM, Montgomery, JM, Fox, LM, 2014: Soil-transmitted helminth infection and nutritional status among urban slum children in Kenya. Am. J. Trop. Med. Hyg. 90, 2:299-305. UNICEF 2000: Egypt demographic and health survey report, Egypt.

WHO 2006: WHO Multicenter Growth Reference Study Group. WHO Child Growth Standards: Length/height-for-age, Weight-for-age, Weight-for-length, Weight-for-height and Body mass index-for-age: Methods and Development. Wld. Hlth. Orga. Geneva.

WHO/WER 2006: Schistosomiasis and soiltransmitted helminthes infections: Preliminary estimates of the number of children treated with albendazole or mebendazole. Wkly. Epidemiol. Rec. 81, 16:145-64.

Youssef, FG, Adib, I, Riddle M, Schlett, C, 2008: Review of cryptosporidiosis in Egypt. J. Egypt. Soc. Parasitol. 38, 1:9-28. 